\title{
Post-mortem changes in three fresh water eels, Mastacembelus armatus, Macrognathus aculeatus and Mastacembelus pancalus during ice storage
}

\author{
MD. ISMAIL HOSSAIN, FATEMA HOQUE SHIKHA* AND MAHMUDUL HASAN \\ Department of Fisheries Technology \\ Bangladesh Agricultural University, Mymensingh 2202, Bangladesh \\ *Email: shikhafh@bau.edu.bd
}

\begin{abstract}
The progress of rigor-mortis and the post-mortem changes in three species of freshwater eels during storage at room temperature $\left(30^{\circ}\right.$ to $\left.35^{\circ} \mathrm{C}\right)$ and ice $\left(0^{\circ} \mathrm{C}\right)$ were studied. Rigor-mortis in fish sample at room temperature, started $1 \mathrm{hr}$ after spiking and it reached to a maximum of $76 \%, 57.14 \%$ and $100 \%$ within 4 hrs after death in Mastacembelus armatus (Baim), Macrognathus aculeatus (Tara baim) and in Mastacembelus pancalus (Guchi), respectively. In ice stored eels rigor also started within one hour of spiking and gradually reached to a maximum of $88.89 \%$ within $3 \mathrm{hrs}$ in Baim and $85.71 \%, 100 \%$ in Tara baim and in Guchi respectively within 2 hrs. Rigor continued for 17,14 and $18 \mathrm{hrs}$ in Baim, Tara baim and Guchi, respectively and then started to relax. The $\mathrm{pH}$ of the muscle was $6.84,6.80$ and 6.92 immediately after catch in Baim, Tara baim and in Guchi, respectively which decreased gradually with the lapse of storage period regardless of the storage temperature. The organoleptic quality of eels during ice storage was assessed on the basis of sensory parameters. Baim was found in acceptable conditions for 24 days whereas Tara baim and Guchi were in acceptable condition for 28 days in ice storage. Percent moisture content increased but protein and lipid contents decreased in almost all the fish samples with the lapse of storage period but a little change was observed in ash content. The TVB-N, peroxide and NPN value remained within the recommended value up to 24 days in Baim and 28 days in Tara baim and Guchi. The initial bacterial loads were $6.5 \times 10^{3}$, $6.2 \times 10^{3}$ And $6.3 \times 10^{3} \mathrm{CFU} / \mathrm{g}$ in Baim, Tara baim and in Guchi, respectively. At the end of the 24 days of ice storage, bacterial load increased in all the fish samples.
\end{abstract}

Key words: Post mortem changes, Rigor, Freshwater eel, Ice storage

\section{Introduction}

Among the fresh water fish species, eels of three species- Baim (Mastacembelus armatus), Tara baim (Macrognathus aculeatus) and Ghuchi/Chirka (Mastacembelus pancalus) are very important due to their high demand to the consumers. These fishes have good market price and they are delicious, nutritious and popular. In our country, fishermen who catch fish by laboring overnight (from common-property water bodies) do not usually sell fish in retail markets. At the break of day, they take their catches to places where Nikaries/Beparies, or retailers, meet them and bargain by the lot. The supply of good quality raw materials is an essential prerequisite for either domestic consumption or value added activities for export in the international market. There are a number of factors that influence the quality of fish. Of which the most important one is the post-mortem changes that take place soon after death due to enzymatic action. One of these reactions is the gradual hydrolysis during the first few hours of glycogen to lactic acid, resulting when the process is complete in a fall in $\mathrm{pH}$ from about 7.0 to 6.8 depending on species and the condition to the fish. The decline in $\mathrm{pH}$ is accompanied by the natural postmortem stiffening called rigor mortis. It is well accepted that- at high temperatures, the onset and duration of rigor mortis are more rapid, but observations, especially on tropical fish show the opposite effect of temperature with regard to the onset of rigor. It is evident that the onset of 
rigor is accelerated at $0^{\circ} \mathrm{C}$ compared to $10^{\circ} \mathrm{C}$ in these species, which is in good correlation with a stimulation of biochemical changes at $0^{\circ} \mathrm{C}$ (Poulter et al. 1982, Iwamoto et al. 1987). However, Abe and Okuma (1991) suggested an explanation for this, onset of rigor mortis in carp (Cyprinus carpio) depends on the difference in sea temperature and storage temperature. When the difference is large the time from death to onset of rigor is short and vice versa.

There are some parameters which also determine the quality of fish during ice storage. Such as- freshness test, $\mathrm{pH}$, TVB-N value, peroxide value, NPN, bacterial loads etc. Freshness test of the fishes indicate the quality test in terms of odor, color and appearance in different species. $\mathrm{pH}$ of the fishes is important indicator to determine the quality of fish in the beginning of the study. The $\mathrm{pH}$ decrease due to increase of acidic compound and finally $\mathrm{pH}$ increases due to increase of basic compound. Loss of water has a detrimental effect on the texture of fish muscle and there is an inverse relationship between muscle toughness and $\mathrm{pH}$, unacceptable levels of toughness (and water-loss on cooking) occurring at lower $\mathrm{pH}$ levels The TVB-N, Peroxide and NPN values gradually increase with lapse of storage time than initial values obtained for fresh fish. However, the scientific and practical knowledge on the keeping qualities of tropical or subtropical fishes is very limited. In recent years, the importance of storage temperature and $\mathrm{pH}$ for the quality of fish muscle proteins have been realized. Considerable information is available on the post-mortem quality changes in fish from temperate and cold waters but very little is known on the fish species of the warm waters, particularly freshwater eels which are commercially and nutritionally very important in this region. Therefore, in the present study, eels of three speciesBaim (M. armatus), Tara baim (M. aculeatus), Ghuchi (M. pancalus) were used to carry out the study on the progress of rigor-mortis of three species of eel, changes in their muscle $\mathrm{pH}$ during storage at room temperature and in ice. The other objective of the study was to observe changes in physical, biochemical and bacteriological parameters of the fishes during ice storage.

\section{Materials and Methods}

Fish Sample: Live specimens of freshwater eels Mastacembelus armatus (Baim), Macrognathus aculeatus (Tara baim) and Mastacembelus pancalus (Guchi) were collected from the K.R. Market of Bangladesh Agricultural University Campus and brought to the laboratory. After cranial spiking the samples were kept in ice $\left(0^{\circ} \mathrm{C}\right)$ and at room temperature $\left(30^{\circ}\right.$ to $\left.35^{\circ} \mathrm{C}\right)$. Total body length of Baim, Tara baim and Guchi, used for the determination of rigor index (Plate-I) at room temperature were $26.00,11.50$, and $19.00 \mathrm{~cm}$, respectively and $23.50,10,00$ and18.50 $\mathrm{cm}$, respectively stored in ice.

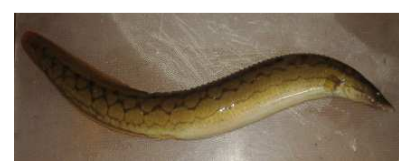

(a)

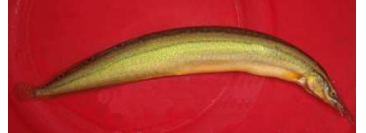

(b)

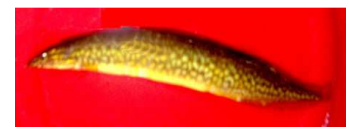

(c)

Plate I. (a) M. armatus); (b) M. aculeatus; (c) M. pancalus

Determination of Rigor Index and pH: "Rigor index" of the fish was measured according to the method described by Bito et al. (1983) and used as a parameter of rigor tension. Briefly, the fish immediately after bringing to the laboratory in live condition and cranial spiking was placed on a horizontal table in such a way that half of its body (tail part) spread out 
of the table. At selected time intervals, rigor index was calculated using the following formula:

$$
\text { Rigor Index }(\%)=\frac{\mathrm{D}_{\mathrm{o}}-\mathrm{D}}{\mathrm{D}_{\mathrm{o}}} \times 100
$$

Where, $\mathrm{D}_{\mathrm{o}}$ and $\mathrm{D}$ represent the distances of the base of caudal fin from horizontal line of the table at the start of the experiment and at subsequent storage period, respectively. During the time of rigor index measurement, $\mathrm{pH}$ was measured following the method described by AOAC (2005).

Organoleptic evaluation: The guidelines and methods described by EC freshness grade for fishery products (Howgate et al. 1992) were used as shown in Table I and II.

Table I. Grading of fresh fish

\begin{tabular}{|l|l|l|}
\hline Grade & Points & Degree of freshness \\
\hline A & $<2$ & Excellent/Acceptable \\
\hline B & 2 to $<5$ & Good/Acceptable \\
\hline C & 5 & Bad Rejected \\
\hline
\end{tabular}

Table II. Determination of defect points

\begin{tabular}{|c|c|c|c|}
\hline $\begin{array}{l}\text { Characteristics } \\
\text { of whole fish }\end{array}$ & Defect characteristics & $\begin{array}{l}\text { Defect } \\
\text { points }\end{array}$ & Grade \\
\hline $\begin{array}{l}\text { Odor of neck } \\
\text { when broken }\end{array}$ & $\begin{array}{l}\text { a) Natural odor } \\
\text { b) Faint or sour odor }\end{array}$ & $\begin{array}{l}2 \\
5 \\
\end{array}$ & $\begin{array}{c}\text { Acceptable } \\
\text { Reject }\end{array}$ \\
\hline Odor of gills & $\begin{array}{l}\text { a) Natural odor } \\
\text { b) Faint sour odor } \\
\text { c) Slight moderate sour odor } \\
\text { d) Moderate to strong sour odor }\end{array}$ & $\begin{array}{l}1 \\
2 \\
3 \\
5\end{array}$ & $\begin{array}{l}\text { Excellent } \\
\text { Acceptable } \\
\text { Acceptable } \\
\text { Reject }\end{array}$ \\
\hline Color of gills & $\begin{array}{l}\text { a) Slight pinkish red } \\
\text { b) Pinkish red or brownish red., some mucus may be present } \\
\text { c) Brown of gray color covered with mucus } \\
\text { d) Bleached; thick yellow slime }\end{array}$ & $\begin{array}{l}1 \\
2 \\
3 \\
5\end{array}$ & $\begin{array}{l}\text { Excellent } \\
\text { Acceptable } \\
\text { Acceptable } \\
\text { Reject }\end{array}$ \\
\hline General appearance & $\begin{array}{l}\text { a) Full bloom; bright; shining; iridescent } \\
\text { b) Slight dullness and loss of bloom } \\
\text { c) Definite dullness and loss of bloom } \\
\text { d) Reddish lateral line; dull; no bloom }\end{array}$ & $\begin{array}{l}1 \\
2 \\
3 \\
5\end{array}$ & $\begin{array}{l}\text { Excellent } \\
\text { Acceptable } \\
\text { Acceptable } \\
\text { Reject }\end{array}$ \\
\hline Eyes & $\begin{array}{l}\text { a) Bulging with protruding lens; transparent eye cap } \\
\text { b) Slight clouding of lens and sunken } \\
\text { c) Dull, sunken, cloudy } \\
\text { d) Sunken dye covered with yellow slime }\end{array}$ & $\begin{array}{l}1 \\
2 \\
3 \\
5\end{array}$ & $\begin{array}{l}\text { Excellent } \\
\text { Acceptable } \\
\text { Acceptable } \\
\text { Reject }\end{array}$ \\
\hline Slime & $\begin{array}{l}\text { a) Usually clear, transparent and uniformly spread but } \\
\text { occasionally may be slightly opaque or milky } \\
\text { b) Becoming turbid opaque and milky, with marked increase } \\
\text { in amount of slime present in skin } \\
\text { c) Thick, sticky, yellowish greenish in color }\end{array}$ & $\begin{array}{l}1 \\
1 \\
5\end{array}$ & $\begin{array}{c}\text { Acceptable } \\
\text { Acceptable } \\
\text { Reject }\end{array}$ \\
\hline $\begin{array}{l}\text { Consistency of } \\
\text { flesh }\end{array}$ & $\begin{array}{l}\text { a) Firm and elastic } \\
\text { b) Moderately soft and some loss of elasticity } \\
\text { c) Some softening } \\
\text { d) Limp and floppy }\end{array}$ & $\begin{array}{l}1 \\
2 \\
3 \\
5\end{array}$ & $\begin{array}{c}\text { Acceptable } \\
\text { Acceptable } \\
\text { Acceptable } \\
\text { Reject }\end{array}$ \\
\hline
\end{tabular}


Analytical methods. Percent proximate composition of fish muscles and the total volatile base nitrogen (TVB-N) was determined according to the methods given in AOAC (1990) with certain modification. The peroxide value was determined by the method described by Egan et al (1981). Total non-protein nitrogen (NPN) was determined essentially following the procedure of Konusu et al. (1974). Aerobic plate count (APC) expressed as colony forming units per gram $(\mathrm{CFU} / \mathrm{g})$ of fish sample on different days of ice storage were determined by consecutive decimal dilution techniques described by Seely and Vandemark (1972).

Data analysis: After collecting various data, statistical analysis was done to know the variance between different answers and the significant level of those results. Data were processed using Microsoft Excel.

\section{Results}

Changes in Rigor Index: The progress of rigor mortis was more rapid in fish stored at room temperature than that in ice. For fish kept at room temperature, rigor started $1 \mathrm{~h}$ after spiking and it reached to a maximum of $76 \%, 57.14 \%$ and $100 \%$ within $4 \mathrm{~h}$ after death in Baim, Tara baim and Guchi, respectively. In ice stored eels, rigor also started within $1 \mathrm{~h}$ and reached to a maximum value of $88.89 \%$ within $3 \mathrm{~h}$ in case of Baim and $85.71 \%$ and $100 \%$ in Tara baim and in Guchi within $2 \mathrm{~h}$, respectively. At this level, they continued for 17, 14 and $18 \mathrm{~h}$ in case of Baim, Tara baim and Guchi, respectively and then started to relax. The rigor relaxed up to $22.22,21.43$ and $16.67 \%$ within 34,32 and $36 \mathrm{~h}$ in Baim, Tara baim and in Guchi, respectively without emitting a foul odor. The study showed that only Guchi reached full rigor in both temperatures (Table III).

Changes in pH: Immediately after bringing to the laboratory, the $\mathrm{pH}$ of the muscle of Baim, Tara baim and in Guchi were 6.84, 6.80 and 6.92, respectively (Table IV). It started to decrease gradually with the lapse of storage period regardless of the storage temperature (either $0^{\circ} \mathrm{C}$ or $30^{\circ}$ to $35^{\circ} \mathrm{C}$ ). But the rate of decrease in $\mathrm{pH}$ in samples stored at room temperature was much rapid than those stored in ice. The ultimate $\mathrm{pH}$ values were observed $6.70,6.65$ and 6.72 at room temperature and 6.10, 6.05 and 6.15 in ice in Baim, Tara baim and in Guchi, respectively after $20 \mathrm{~h}$ of storage.

Changes in organoleptic characteristics: On the basis of the score parameters mentioned in Table I and Table II, Baim was found in acceptable condition for 24 days while Tara baim and Guchi were found in acceptable condition for 28 days of ice storage before it became inedible (Table V). During this period, changes in quality can roughly be divided into 8 steps corresponding 0 to 4,5 to 8,9 to 12,13 to 16,17 to $20,21-24,25$ to 28 and 29 to 32 days in ice. There were very little changes occurred in step 1 ( 0 to 4 days) and 2 (5 to 8 days) without loss of natural flavor and odor in all experimental eels. In step 3 (9 to 12 days), 4 (13 to 16 days) and 5 (17 to 20 days) there were slight loss of natural flavor and odor, considerable loss of flavor and odor and loss of bloom respectively in all experimental species. Fishes are acceptable in this condition. In case of Baim in step 6 (21-24 days) fishes had dull appearance with blood and showed obvious signs of spoilage. In this condition they were in the limit of acceptance. In step 7 ( 25 to 28 days), Baim was putrid all of the characteristics and thus rejected. On the other hand Tara baim and Guchi in step 6 (21-24 days) moderate losses of flavor and odor and they are acceptable in this condition. In step 7 (25 to 28 days), they were dull appearance with blood 
POST-MORTEM CHANGES IN THREE FRESH WATER EELS DURING ICE STORAGE

and showed obvious sings of spoilage and in the limit of acceptance. In step 8 (29 to 32 days), they were putrid all of the characteristics and hence rejected.

Table III. Changes in rigor- index of M. armatus, M. aculeatus, and M. pancalus stored at room temperature and in ice

\begin{tabular}{|c|c|c|c|c|c|c|}
\hline \multirow{2}{*}{$\begin{array}{c}\text { Time (hours)/ } \\
\text { Rigor Index (\%) }\end{array}$} & \multicolumn{3}{|c|}{ Room temperature $\left(30^{\circ}\right.$ to $\left.35^{\circ} \mathrm{C}\right)$} & \multicolumn{3}{|c|}{ In ice $\left(0^{\circ} \mathrm{C}\right)$} \\
\hline & $\begin{array}{c}M . \\
\text { armatus }\end{array}$ & $\begin{array}{c}M . \\
\text { aculeatus }\end{array}$ & $\begin{array}{c}M . \\
\text { pancalus }\end{array}$ & $\begin{array}{c}M . \\
\text { armatus }\end{array}$ & $\begin{array}{c}M . \\
\text { aculeatus }\end{array}$ & $\begin{array}{c}M . \\
\text { pancalus }\end{array}$ \\
\hline 1 & 4.00 & 14.29 & 20.00 & 33.33 & 35.71 & 33.33 \\
\hline 2 & 12.00 & 28.57 & 40.00 & 66.67 & 57.14 & 66.67 \\
\hline 3 & 33.33 & 35.71 & 60.00 & 77.78 & 85.71 & 100.00 \\
\hline 4 & 56.00 & 42.86 & 80.00 & 88.89 & 85.71 & 100.00 \\
\hline 5 & 76.00 & 57.14 & 100.00 & 88.89 & 85.71 & 100.00 \\
\hline 6 & 76.00 & 57.14 & 100.00 & 88.89 & 85.71 & 100.00 \\
\hline 7 & 76.00 & 50.00 & 100.00 & 88.89 & 85.71 & 100.00 \\
\hline 8 & 72.00 & 42.86 & 100.00 & 88.89 & 85.71 & 100.00 \\
\hline 9 & 64.00 & 21.43 & 90.00 & 88.89 & 85.71 & 100.00 \\
\hline 10 & 56.00 & 14.29 & 80.00 & 88.89 & 85.71 & 100.00 \\
\hline 11 & 44.00 & 7.14 & 70.00 & 88.89 & 85.71 & 100.00 \\
\hline 12 & 33.33 & 0.00 & 60.00 & 88.89 & 85.71 & 100.00 \\
\hline 13 & 16.00 & & 40.00 & 88.89 & 85.71 & 100.00 \\
\hline 14 & 0.00 & & 20.00 & 88.89 & 85.71 & 100.00 \\
\hline 15 & & & 0.00 & 88.89 & 85.71 & 100.00 \\
\hline 16 & & & & 88.89 & 85.71 & 100.00 \\
\hline 17 & & & & 88.89 & 78.57 & 100.00 \\
\hline 18 & & & & 88.89 & 71.43 & 100.00 \\
\hline 20 & & & & 88.89 & 64.29 & 100.00 \\
\hline 22 & & & & 83.33 & 57.14 & 83.33 \\
\hline 24 & & & & 77.78 & 50.00 & 75.00 \\
\hline 26 & & & & 66.67 & 42.86 & 66.67 \\
\hline 28 & & & & 55.56 & 35.71 & 58.33 \\
\hline 30 & & & & 44.44 & 28.57 & 50.00 \\
\hline 32 & & & & 33.33 & 21.43 & 33.33 \\
\hline 36 & & & & 88.89 & 85.71 & 100.00 \\
\hline
\end{tabular}

Table IV. Changes in pH of M. armatus, M. aculeatus, M. pancalus at room temperature and in ice

\begin{tabular}{|c|c|c|c|c|c|c|}
\hline \multirow{2}{*}{$\begin{array}{c}\text { Time } \\
\text { (hours) }\end{array}$} & \multicolumn{6}{|c|}{$\mathrm{P}^{\mathrm{H}}$} \\
\cline { 2 - 7 } & \multicolumn{2}{|c|}{ Room temperature $\left(30^{\circ}\right.$ to $\left.35^{\circ} \mathrm{C}\right)$} & \multicolumn{3}{c|}{ Ice temperature $\left(0^{\circ} \mathrm{C}\right)$} \\
\cline { 2 - 7 } & M. armatus & M. aculeatus & M. pancalus & M. armatus & M. aculeatus & M. pancalus \\
\hline 0 & 6.88 & 6.85 & 6.92 & 6.88 & 6.85 & 6.92 \\
\hline 2 & 6.84 & 6.80 & 6.86 & 6.86 & 6.82 & 6.89 \\
\hline 4 & 6.70 & 6.68 & 6.72 & 6.82 & 6.78 & 6.85 \\
\hline 6 & 6.62 & 6.58 & 6.65 & 6.77 & 6.73 & 6.80 \\
\hline 8 & 6.50 & 6.45 & 6.55 & 6.70 & 6.66 & 6.72 \\
\hline 10 & 6.35 & 6.32 & 6.40 & 6.62 & 6.58 & 6.64 \\
\hline 12 & 6.20 & 6.15 & 6.25 & 6.50 & 6.45 & 6.52 \\
\hline 14 & 6.35 & 6.30 & 6.38 & 6.37 & 6.32 & 6.38 \\
\hline 16 & 6.45 & 6.42 & 6.50 & 6.22 & 6.22 & 6.25 \\
\hline 18 & 6.60 & 6.58 & 6.65 & 6.15 & 6.12 & 6.20 \\
\hline 20 & 6.78 & 6.72 & 6.80 & 6.10 & 6.05 & 6.15 \\
\hline
\end{tabular}


MD. ISMAIL HOSSAIN et al.

Table V. Changes in organoleptic qualities of M. armatus, M. aculeatus and M. pancalus during ice storage in insulated box

\begin{tabular}{|c|c|c|c|c|c|c|c|c|c|c|}
\hline \multirow{2}{*}{$\begin{array}{l}\text { Days } \\
\text { of } \\
\text { storage }\end{array}$} & \multirow[t]{2}{*}{ Organoleptic qualities } & \multicolumn{3}{|c|}{ Mastacembelus armatus } & \multicolumn{3}{|c|}{ Macrognathus aculeatus } & \multicolumn{3}{|c|}{ Mastacembelus pancalus } \\
\hline & & $\begin{array}{l}\text { Defect } \\
\text { points }\end{array}$ & Grade & $\begin{array}{c}\text { Overall } \\
\text { qualities }\end{array}$ & $\begin{array}{l}\text { Defect } \\
\text { points }\end{array}$ & Grade & $\begin{array}{c}\text { Overall } \\
\text { qualities }\end{array}$ & $\begin{array}{l}\text { Defect } \\
\text { points }\end{array}$ & Grade & $\begin{array}{c}\text { Overall } \\
\text { qualities }\end{array}$ \\
\hline 0 & $\begin{array}{lr}\text { Fresh, } & \text { bright } \\
\text { appearance, soft and } \\
\text { firm texture with } \\
\text { characteristics } \\
\text { natural fishy odor. }\end{array}$ & 1.25 & A & Excellent & 1.25 & A & Excellent & 1.25 & A & Excellent \\
\hline 4 & $\begin{array}{l}\text { A decrease in the } \\
\text { brightness; slightly } \\
\text { softer texture, natural } \\
\text { fishy odor. }\end{array}$ & 1.6 & A & Excellent & 1.6 & A & Excellent & 1.6 & A & Excellent \\
\hline 8 & $\begin{array}{l}\text { Some loss in } \\
\text { brightness; slight loss } \\
\text { of the natural flavor; } \\
\text { some slime in the } \\
\text { surface. }\end{array}$ & 2.2 & B & Acceptable & 2.1 & B & Acceptable & 2.1 & B & Acceptable \\
\hline 12 & $\begin{array}{l}\text { Slimy surface and } \\
\text { slight soft texture; } \\
\text { considerable loss of } \\
\text { flavor and odor. }\end{array}$ & 2.6 & B & Acceptable & 2.5 & B & Acceptable & 2.5 & B & Acceptable \\
\hline 16 & $\begin{array}{l}\text { Moderately soft texture } \\
\text { and slime on surface; } \\
\text { loss of bloom. }\end{array}$ & 3.2 & B & Acceptable & 2.9 & $\mathrm{~B}$ & Acceptable & 2.9 & B & Acceptable \\
\hline 20 & $\begin{array}{l}\text { Soft texture and slime } \\
\text { on surface; moderate } \\
\text { loss of flavor and odor. }\end{array}$ & 3.6 & B & Acceptable & 3.4 & B & Acceptable & 3.4 & B & Acceptable \\
\hline 24 & $\begin{array}{l}\text { Fish has dull } \\
\text { appearance with blood } \\
\text { and slime on surface } \\
\text { not uniformly } \\
\text { distributed; texture } \\
\text { begin to show obvious } \\
\text { signs of spoilage. }\end{array}$ & 4.5 & B & $\begin{array}{l}\text { In the limit } \\
\text { Acceptable }\end{array}$ & 3.85 & B & Acceptable & 3.8 & B & Acceptable \\
\hline 28 & $\begin{array}{l}\text { The fish is putrid by all } \\
\text { of the characteristics. }\end{array}$ & 5.0 & $\mathrm{C}$ & Rejected & 4.5 & B & $\begin{array}{l}\text { In the limit } \\
\text { Acceptable }\end{array}$ & 4.5 & B & Acceptable \\
\hline 32 & $\begin{array}{l}\text { The fish is putrid by all } \\
\text { of the characteristics. }\end{array}$ & & & & 5.0 & $\mathrm{C}$ & Rejected & 5.0 & $\mathrm{C}$ & Rejected \\
\hline
\end{tabular}

\section{Changes in biochemical parameters}

Proximate composition: Moisture, protein, lipid and ash contents in the muscles immediately after death were $79.20 \pm 1.77,15.40 \pm 1.10,4.47 \pm 0.72$ and $1.77 \pm 0.15 \%$; $78.54 \pm 1.7$, $14.68 \pm 0.57,5.52 \pm 1.11$ and $1.62 \pm 0.09 \%$; and $78.50 \pm 1.34,15.34 \pm 1.23,4.77 \pm 0.70$ and $1.72 \pm 0.06 \%$ in Baim, Tara baim and Guchi Respectively (Table VI). Moisture content increased gradually with storage period and at end of 32 days of ice storage it increased from $79.20 \pm 1.77$ to $85.33 \pm 1.24 \%, 78.54 \pm 1.17$ to $84.30 \pm 1.04 \%$ and $78.50 \pm 1.34$ to $85.17 \pm 1.13 \%$ in Baim, Tara baim and Guchi respectively. Protein content gradually decreased from $15.74 \pm 1.10$ to $12.30 \pm 1.73 \%, 14.68 \pm 0.57$ to $10.73 \pm 0.65 \%$ and $15.34 \pm 1.23$ to $12.20 \pm 1.10 \%$ in Baim, Tara baim and in Guchi respectively. Again lipid content decreased from $4.47 \pm 0.72$ to $1.80 \pm 0.12 \%, 5.52 \pm 1.11$ to $2.20 \pm 0.12 \%$ and $4.77 \pm 0.70$ to $2.00 \pm 0.06 \%$ in Baim, Tara baim and Guchi respectively. Ash consent showed very little change. 
POST-MORTEM CHANGES IN THREE FRESH WATER EELS DURING ICE STORAGE

Table VI. Changes in proximate compositions ((Mean \pm SE) of $M$. armatus, M. aculeatus and $M$. pancalus during ice storage in insulated box

\begin{tabular}{|c|c|c|c|c|c|c|c|c|c|c|c|c|}
\hline \multirow[b]{2}{*}{$\begin{array}{l}\text { Days of } \\
\text { storage }\end{array}$} & \multicolumn{4}{|c|}{ M. armatus } & \multicolumn{4}{|c|}{ M. aculeatus } & \multicolumn{4}{|c|}{ M. pancalus } \\
\hline & $\begin{array}{c}\text { Moisture } \\
(\%)\end{array}$ & $\begin{array}{c}\text { Protein } \\
(\%)\end{array}$ & $\begin{array}{c}\text { Lipid } \\
(\%)\end{array}$ & $\begin{array}{l}\text { Ash } \\
(\%)\end{array}$ & $\begin{array}{c}\text { Moisture } \\
(\%)\end{array}$ & $\begin{array}{c}\text { Protein } \\
(\%)\end{array}$ & $\begin{array}{c}\text { Lipid } \\
(\%)\end{array}$ & $\begin{array}{l}\text { Ash } \\
(\%)\end{array}$ & $\begin{array}{c}\text { Moisture } \\
(\%)\end{array}$ & $\begin{array}{c}\text { Protein } \\
(\%)\end{array}$ & $\begin{array}{c}\text { Lipid } \\
(\%)\end{array}$ & $\begin{array}{l}\text { Ash } \\
(\%)\end{array}$ \\
\hline 0 & $\begin{array}{l}79.20 \\
\pm 1.77 \\
\end{array}$ & $\begin{array}{l}15.40 \\
\pm 1.10 \\
\end{array}$ & $\begin{array}{c}4.47 \\
\pm 0.72 \\
\end{array}$ & $\begin{array}{c}1.77 \\
\pm 0.15 \\
\end{array}$ & $\begin{array}{r}78.54 \\
\pm 1.17 \\
\end{array}$ & $\begin{array}{l}14.68 \\
\pm 0.57 \\
\end{array}$ & $\begin{array}{c}5.52 \\
\pm 1.11 \\
\end{array}$ & $\begin{array}{c}1.62 \\
\pm 0.09 \\
\end{array}$ & $\begin{array}{r}78.50 \\
\pm 1.34 \\
\end{array}$ & $\begin{array}{l}15.34 \\
\pm 1.23 \\
\end{array}$ & $\begin{array}{c}4.77 \\
\pm 0.70 \\
\end{array}$ & $\begin{array}{c}1.72 \\
\pm 0.06 \\
\end{array}$ \\
\hline 4 & $\begin{array}{l}79.72 \\
\pm 1.16\end{array}$ & $\begin{array}{l}15.43 \\
\pm 1.76\end{array}$ & $\begin{array}{c}4.24 \\
\pm 0.63\end{array}$ & $\begin{array}{c}1.80 \\
\pm 0.12\end{array}$ & $\begin{array}{l}79.10 \\
\pm 0.52\end{array}$ & $\begin{array}{c}14.54 \\
\pm 1.16\end{array}$ & $\begin{array}{c}5.20 \\
\pm 0.12\end{array}$ & $\begin{array}{c}1.65 \\
\pm 0.17\end{array}$ & $\begin{array}{l}79.31 \\
\pm 2.14\end{array}$ & $\begin{array}{l}15.00 \\
\pm 0.58\end{array}$ & $\begin{array}{c}4.60 \\
\pm 0.67\end{array}$ & $\begin{array}{c}1.72 \\
\pm 0.04\end{array}$ \\
\hline 8 & $\begin{array}{l}80.20 \\
\pm 1.77 \\
\end{array}$ & $\begin{array}{r}15.30 \\
\pm 1.71 \\
\end{array}$ & $\begin{array}{c}4.00 \\
\pm 0.58 \\
\end{array}$ & $\begin{array}{c}1.79 \\
\pm 0.06 \\
\end{array}$ & $\begin{array}{l}79.28 \\
\pm 1.72 \\
\end{array}$ & $\begin{array}{r}14.30 \\
\pm 0.55 \\
\end{array}$ & $\begin{array}{c}5.00 \\
\pm 0.58 \\
\end{array}$ & $\begin{array}{c}1.63 \\
\pm 0.17 \\
\end{array}$ & $\begin{array}{l}79.61 \\
\pm 1.17 \\
\end{array}$ & $\begin{array}{l}14.62 \\
\pm 1.15 \\
\end{array}$ & $\begin{array}{c}4.40 \\
\pm 0.47 \\
\end{array}$ & $\begin{array}{c}1.70 \\
\pm 0.03 \\
\end{array}$ \\
\hline 12 & $\begin{array}{l}80.78 \\
\pm 2.90\end{array}$ & $\begin{array}{l}14.49 \\
\pm 1.16\end{array}$ & $\begin{array}{c}3.76 \\
\pm 0.67\end{array}$ & $\begin{array}{c}1.90 \\
\pm 0.06\end{array}$ & $\begin{array}{l}80.27 \\
\pm 2.77\end{array}$ & $\begin{array}{r}13.73 \\
\pm 1.01\end{array}$ & $\begin{array}{c}4.71 \\
\pm 0.64\end{array}$ & $\begin{array}{c}1.65 \\
\pm 0.23\end{array}$ & $\begin{array}{l}80.20 \\
\pm 1.13\end{array}$ & $\begin{array}{c}14.42 \\
\pm 0.64\end{array}$ & $\begin{array}{c}4.40 \\
\pm 0.55\end{array}$ & $\begin{array}{c}1.72 \\
\pm 0.01\end{array}$ \\
\hline 16 & $\begin{array}{l}81.80 \\
\pm 0.72\end{array}$ & $\begin{array}{l}14.08 \\
\pm 1.69\end{array}$ & $\begin{array}{c}3.32 \\
\pm 0.63\end{array}$ & $\begin{array}{c}1.83 \\
\pm 0.20\end{array}$ & $\begin{array}{l}80.68 \\
\pm 1.21\end{array}$ & $\begin{array}{l}13.54 \\
\pm 1.09\end{array}$ & $\begin{array}{c}4.50 \\
\pm 0.52\end{array}$ & $\begin{array}{c}1.68 \\
\pm 0.06\end{array}$ & $\begin{array}{l}80.64 \\
\pm 2.92\end{array}$ & $\begin{array}{l}14.35 \\
\pm 0.64\end{array}$ & $\begin{array}{c}4.00 \\
\pm 0.58\end{array}$ & $\begin{array}{c}1.72 \\
\pm 0.06\end{array}$ \\
\hline 20 & $\begin{array}{l}82.40 \\
\pm 0.99\end{array}$ & $\begin{array}{l}13.43 \\
\pm 1.67\end{array}$ & $\begin{array}{c}2.79 \\
\pm 0.68\end{array}$ & $\begin{array}{c}1.79 \\
\pm 0.07\end{array}$ & $\begin{array}{l}81.50 \\
\pm 0.64\end{array}$ & $\begin{array}{l}13.40 \\
\pm 0.63\end{array}$ & $\begin{array}{c}4.15 \\
\pm 1.14\end{array}$ & $\begin{array}{c}1.67 \\
\pm 0.11\end{array}$ & $\begin{array}{l}81.38 \\
\pm 0.55\end{array}$ & $\begin{array}{l}14.27 \\
\pm 1.82\end{array}$ & $\begin{array}{c}3.76 \\
\pm 0.53\end{array}$ & $\begin{array}{c}1.70 \\
\pm 0.06\end{array}$ \\
\hline 24 & $\begin{array}{l}83.47 \\
\pm 1.21 \\
\end{array}$ & $\begin{array}{l}13.00 \\
\pm 0.58 \\
\end{array}$ & $\begin{array}{c}2.60 \\
\pm 0.23 \\
\end{array}$ & $\begin{array}{c}1.80 \\
\pm 0.17 \\
\end{array}$ & $\begin{array}{l}82.57 \\
\pm 1.20 \\
\end{array}$ & $\begin{array}{l}13.00 \\
\pm 0.58 \\
\end{array}$ & $\begin{array}{c}3.50 \\
\pm 0.58 \\
\end{array}$ & $\begin{array}{c}1.65 \\
\pm 0.05 \\
\end{array}$ & $\begin{array}{l}81.90 \\
\pm 1.77 \\
\end{array}$ & $\begin{array}{l}13.47 \\
\pm 0.56 \\
\end{array}$ & $\begin{array}{c}3.44 \\
\pm 0.52 \\
\end{array}$ & $\begin{array}{r}1.70 \\
\pm 0.12 \\
\end{array}$ \\
\hline 28 & $\begin{array}{l}84.00 \\
\pm 0.58 \\
\end{array}$ & $\begin{array}{l}12.67 \\
\pm 0.66 \\
\end{array}$ & $\begin{array}{c}2.43 \\
\pm 0.15 \\
\end{array}$ & $\begin{array}{c}1.83 \\
\pm 0.09 \\
\end{array}$ & $\begin{array}{l}83.48 \\
\pm 1.21 \\
\end{array}$ & $\begin{array}{c}12.41 \\
\pm 0.66 \\
\end{array}$ & $\begin{array}{c}2.88 \\
\pm 0.56 \\
\end{array}$ & $\begin{array}{c}1.63 \\
\pm 0.02 \\
\end{array}$ & $\begin{array}{l}83.00 \\
\pm 1.15 \\
\end{array}$ & $\begin{array}{c}13.32 \\
\pm 0.61 \\
\end{array}$ & $\begin{array}{c}2.90 \\
\pm 0.63 \\
\end{array}$ & $\begin{array}{c}1.72 \\
\pm 0.06 \\
\end{array}$ \\
\hline 32 & $\begin{array}{l}85.33 \\
\pm 1.24 \\
\end{array}$ & $\begin{array}{l}12.30 \\
\pm 1.73 \\
\end{array}$ & $\begin{array}{c}1.80 \\
\pm 0.12 \\
\end{array}$ & $\begin{array}{c}1.79 \\
\pm 0.12 \\
\end{array}$ & $\begin{array}{l}84.30 \\
\pm 1.04 \\
\end{array}$ & $\begin{array}{l}10.73 \\
\pm 0.65 \\
\end{array}$ & $\begin{array}{c}2.20 \\
\pm 0.12 \\
\end{array}$ & $\begin{array}{c}1.65 \\
\pm 0.06 \\
\end{array}$ & $\begin{array}{l}85.17 \\
\pm 1.13 \\
\end{array}$ & $\begin{array}{l}12.20 \\
\pm 1.10 \\
\end{array}$ & $\begin{array}{c}2.00 \\
\pm 0.06 \\
\end{array}$ & $\begin{array}{c}1.72 \\
\pm 0.01 \\
\end{array}$ \\
\hline
\end{tabular}

TVB-N value: The initial TVB-N values were $6.47 \pm 0.61,6.30 \pm 0.58$ and $6.10 \pm 0.06 \mathrm{mg} / 100 \mathrm{~g}$ in Baim , Tara baim and Guchi, respectively, which gradually increased with lapse of storage period (Fig. 1). At the end of 24 days of ice storage of Baim's TVB-N values increased up to $23 \pm 1.16 \mathrm{mg} / 100$, which is within the range of recommended values of 25 to $30 \mathrm{mg} / 100 \mathrm{~g}$ for fresh fish. In case of Tara baim and in Guchi TVB-N values were $22.30 \pm 1.15$ and $21.00 \pm 1.1 .15 \mathrm{mg} / 100 \mathrm{~g}$, respectively after 28 days of ice storage, which were also within the recommended value for fresh fish. However, at the end of 28 days the TVB-N Values were $32.55 \pm 1.14 \mathrm{mg} / 100 \mathrm{~g}$ for Baim and $35.60 \pm 0.98,33.20 \pm 1.04 \mathrm{mg} / 100 \mathrm{~g}$ for Tara baim, Guchi at the end of 32 days of ice storage that exceeded the recommended values.

Peroxide value: The initial peroxide values were $2.20 \pm 0.12,2.00 \pm 0.58$ and $1.90 \pm 0.6$ $\mathrm{m} . \mathrm{eq} / \mathrm{kg}$ of oil in Baim, Tara baim and in Guchi respectively, which increased gradually with the lapse of storage period (Fig. 2). At the end of 24 days of ice storage of Baimthe peroxide value was $14.20 \pm 0.12 \mathrm{~m} . \mathrm{eq} / \mathrm{kg}$ of oil which was within recommended limit values of 10-20 $\mathrm{m} . \mathrm{eq} / \mathrm{kg}$ of oil. In case of Tara baim and Guchi the peroxide values were $17.30 \pm 1.15$ and $16.25 \pm 1.15 \mathrm{~m} . \mathrm{eq} / \mathrm{kg}$ of oil at the end of 28 days of ice storage, which were also found within recommended values of $10-20 \mathrm{~m}$ eq $/ \mathrm{kg}$ of oil. At the end of 28 days of ice storage of Baim, the peroxide value was $22.80 \pm 1.15 \mathrm{~m} . \mathrm{eq} / \mathrm{kg}$ of oil that exceeded the recommended values. In case of Tara balm and Guchi the peroxide value were $24.20 \pm 0.46$ and $22.89 \pm 1 . \mathrm{m} . \mathrm{eq} / \mathrm{kg}$ of oil at the end of 32 days of ice storage that exceeded the recommended values. 


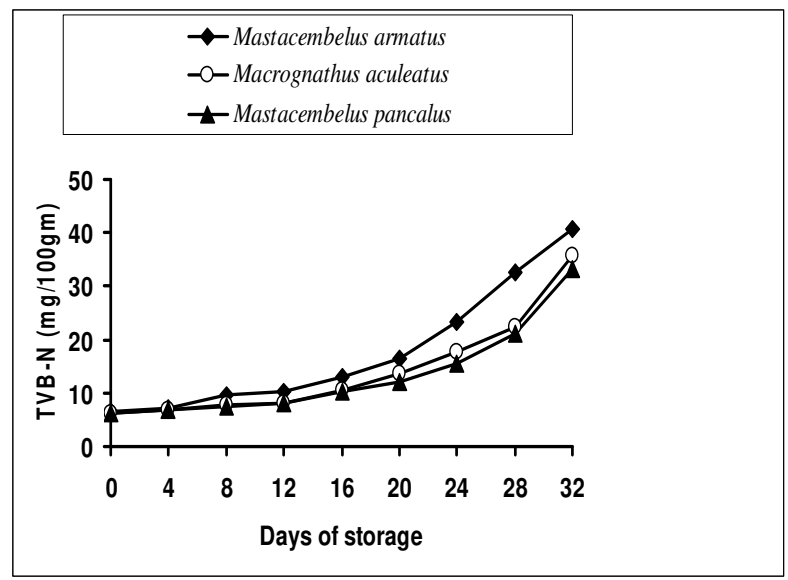

Fig. 1. Changes in Total Volatile Base Nitrogen (mg/100g) in M. armatus, $M$. aculeatus and $M$. pancalus during ice storage in insulated box.

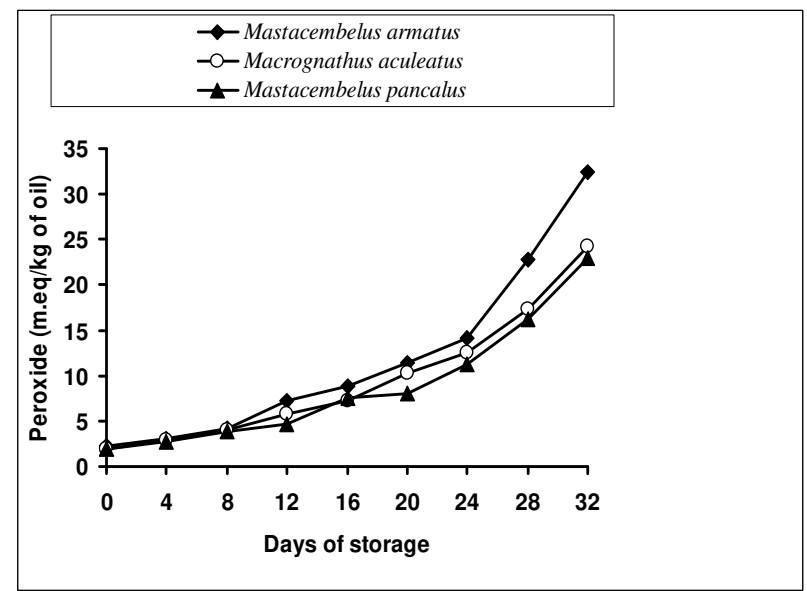

Fig. 2. Changes in peroxide value (m.eq./kg of oil) in M. armatus, M. aculeatus and $M$. pancalus during ice storage in insulated box.

NPN value: The initial NPN values were $0.07 \pm 0.003,0.06 \pm 0.001$ and $0.06 \pm 0.06 \%$ of total nitrogen in Baim, Tara baim and Guchi, respectively (Fig. 3). There was a clear trend of increasing NPN contents with storage period. At the end of 32 days of storage the NPN values increased to $0.23 \pm 0.012,0.19 \pm 0.003$ and $0.21 \pm 0.012 \%$ of total nitrogen in Baim, Tara brim and in Guchi respectively. However, organoleptically the Baim was more or less in acceptable condition up to 24 days of ice storage which corresponds to NPN values of $0.15 \pm 0.023 \%$ of total nitrogen. Again Tara baim and Guchi were acceptable condition up to 28 days of ice storage which corresponds to NPN values of $0.15 \pm 0.006$ and $0.16 \pm 0.029 \%$ respectively. 


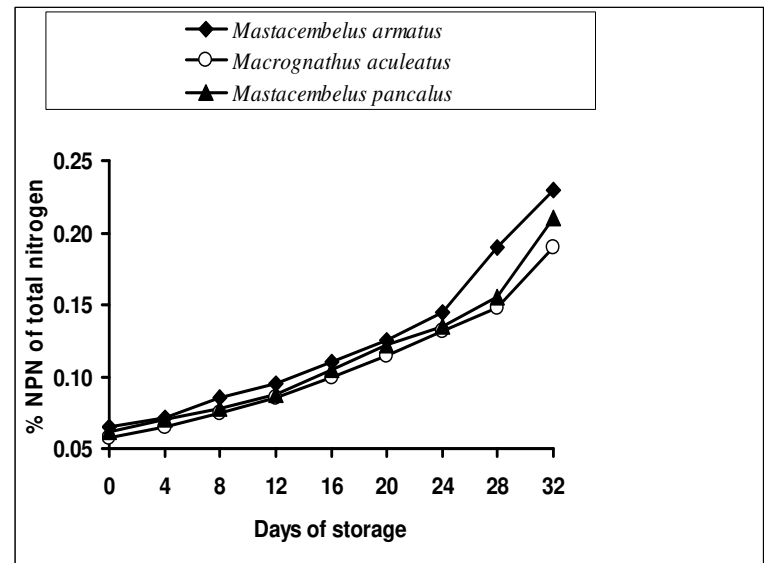

Fig. 3. Changes in Non Protein Nitrogen (\%) in M. armatus, M. aculeatus and $M$. pancalus during ice storage in insulated box.

Changes in bacterial loads: The initial bacterial loads were $6.5 \times 10^{3}, 6.2 \times 10^{3}$ And $6.3 \times 10^{3}$ $\mathrm{CFU} / \mathrm{g}$ in Baim, Tara baim and Guchi, respectively which gradually decreased to $5.8 \times 10^{3}$, $5.5 \times 10^{3}$ and5.6 $\times 10^{3} \mathrm{CFU} / \mathrm{g}$ at $4^{\text {th }}$ days of ice storage in above three species respectively (Fig. 4). The bacterial loads increased gradually with storage period. At the end of the 24 days of ice storage, bacterial load increased to $4.3 \times 10^{6} \mathrm{CFU} / \mathrm{g}$ and at this stage Baims were organoleptically acceptable condition. Again, Tara baim and Guchi were acceptable at the end of 28 days of ice storage with bacterial loads $3.9 \times 10^{6}$ and $4.5 \times 10^{6} \mathrm{CFU} / \mathrm{g}$ respectively. Baims were organoleptically rejected at the end of 28 days of ice storage with bacterial loads $6.7 \times 10^{8}$ $\mathrm{CFU} / \mathrm{g}$. Again, Tara baim and Guchi were rejected at the end of 32 days of ice storage with bacterial loads $8.2 \times 10^{8}$ and $9.0 \times 10^{8} \mathrm{CFU} / \mathrm{g}$ respectively.

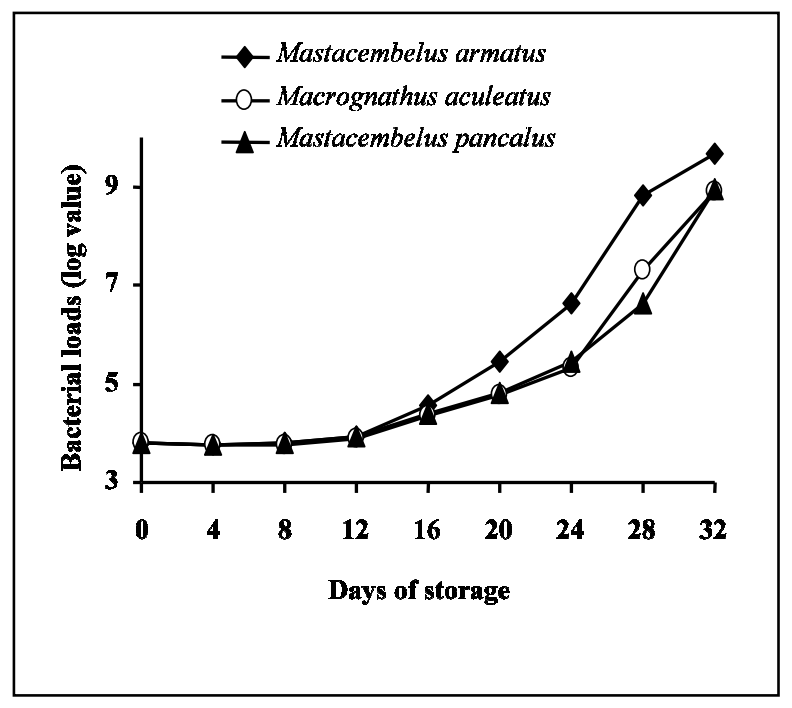

Fig. 4. Bacterial loads in M. armatus, M. aculeatus and M. pancalus during ice storage in insulated box. 


\section{Discussion}

Changes in Rigor Index and pH: Many studies have revealed that the biochemical process leading to rigor-mortis is the same in the muscles of great variety of species of fish and warm blooded animals but the onset and the rate of progress of rigor-mortis varies from species to species and are function of temperature. It has been reported that lower temperature delays the onset of rigor, that is, lengthens the pre-rigor period and also slows down the rate of progress of rigor-mortis (Iwamoto et al. 1987). However, these studies support the findings of the present study with Baim, Tara baim and Guchi which showed- an early onset of rigor and a prolonged period of in-rigor with lower temperature in ice than that of at room temperature. In the present study, during the early post-mortem period, muscle $\mathrm{pH}$ in fish stored at room temperature decreased much faster than that stored at $0^{\circ} \mathrm{C}$, from which it can be assumed that when the onset of rigor is quick and its duration is shorter, the $\mathrm{pH}$ values decline much faster than the case, where rigor develops slowly and lasts longer. This change in rate is due to the accelerated turnover of ATP at high temperature (Watabe et al. 1991).

Changes in organoleptic characteristics: Kamal et al. (1994) reported that- hilsa immediately after catch transported in the insulated box in ice remained in acceptable condition for 18 days of storage, while the fish obtained from Mymensingh wholesale fish market and stored in wooden box were organoleptically acceptable for about 8 days in ice storage. Faruk (1995) found the organoleptic quality of rohu fish during ice storage in an insulated box in acceptable condition for 20 days of storage before it became inedible. Rubbi et al. (1985) studied the shelf life of six freshwater fish species in different storage temperature by subjective and objective parameters. The spoilage rates were found to increase with the increase of storage temperature for all the six varieties. Bamboo baskets and wooden boxes, insulated with hoglamat (the spongy leaves of a local plant), were reported to be most efficient for maintaining the quality of fish in ice for transportation. Hye et al. (1990) suggested that fish-ice ratio of 4:1, 2:1 and 1:1 could preserve the shelf life of fish up to $72 \mathrm{~h}$, $120 \mathrm{~h}$ and $144 \mathrm{~h}$, respectively in the insulating box consisting of polvurethene material. The results obtained in the present study suggest that organoleptically the shelf life of the freshwater eel species is almost similar to that of reported for carps and other commercially fresh water fish species.

Proximate composition: In the present study, moisture content increased in all the fish samples might be due to the absorption of water from surrounding ice and losses of other components. Total crude protein content in fish flesh decreased with the lapse of storage period. Some loss of organic nitrogenous constituents, largely sarcoplasmic proteins and inorganic salts with free drip are probably the contributing factors for such loss (Tarr, 1965). A decrease in lipid content during storage period could be explained by their individual variation and oxidation since lipid content varies greatly even within the same species. The proximate composition of fresh chapila- $77.51 \%$ moisture, $15.59 \%$ protein, $3.58 \%$ fat and $2.75 \%$ ash and tengra- $78.54 \%$ moisture, $17.01 \%$ protein, $2.15 \%$ fat, $2.06 \%$ ash content in edible portion (Chakraborty et al. 2003). All these findings are more or less similar to the obtained results in the present study.

TVB-N and peroxide value: The upper limit of $30 \mathrm{mg}$ TVB- N/100g is considered for finfish acceptability (Connell 1975). The increase in TVB-N with the lapse of storage in the present 
study may be attributed to bacterial spoilage. However, the available information indicates that TVB-N mainly accumulated in the fish flesh during the later phase of spoilage after the bacterial population has grown. Thus the TVB-N is low during the edible storage period and relies when the fish is near rejection level. Also there is a large variation between species in the development of TVB-N values. According to Connell (1975) the recommended values of peroxide for fresh fish is $10-20 \mathrm{~m} . \mathrm{eq} / \mathrm{kg}$ of oil. The value above $20 \mathrm{~m} . \mathrm{eq} / \mathrm{kg}$ of oil, the fish will smell bad and taste rancid. The peroxides are eventually further oxidized to aldehydes and ketones which have a very disagreeable fishy or rancid odor and taste. However depending on the fish species and storage condition a good correlation between peroxide value and organoleptic quality may be found. The present study is the good example of this pattern.

NPN value: NPN content in fish flesh increased gradually with storage period. The deteriorative changes in fish muscle are associated with the hydrolysis of cellular components by intracellular enzyme and bacterial enzyme during post-mortem period. The NPN value may vary considerably from species to species and even among the individuals of the same species due to variety of cause such as sex, age, season feeding habit, spawning cycle etc. Kamal (1977) reported that NPN content in frozen ribbon fish (Trichiurus haumela); Bombay duck (Harpodon neherius) and Indian salmon (Polvnemus indicus) were $0.38,0.36$ and $0.39 \mathrm{~g} / 100 \mathrm{~g}$. Lower NPN values in ice storage in the present study, confirming comparatively the better condition of the product.

Changes in bacterial loads: The initial decrease in bacterial population in the experimental fish muscle after the first days of storage might be due to cold shock or leaching of surface flora by washing with melted ice. It has been reported that the number of bacteria in gill, intestinal content and or the skin of newly caught fish vary from species to species and also depend on the microbial load of the waters in which they live (Fraiger and Westhoff 1990). The bacterial load of the ice-stored fish seemed to directly influence the shelf-life of the fish. Increase in the bacterial number is also accompanied by the increase in the non-protein nitrogen (NPN), TVB-N and peroxide value in the fish muscle. They are generally accepted as the important determinants for the quality of fresh fish. Organoleptic scores (5.0) also had good correlation with the bacterial load in the muscle of ice-stored freshwater eels. It is known that autolytic spoilage process is more active in the early storage period and bacterial spoilage in later storage period. The bacterial spoilage of fish does not begin until after rigor-mortis, when juices are released from the flesh-fiber (Frazier and Westhoff 1990). Therefore, the more the rigor is delayed or prolonged, the longer the keeping quality or shelf-life of the fish.

\section{Conclusions}

The present study concludes that the progress of rigor-mortis in freshwater eels is faster at room temperature than in ice. The $\mathrm{pH}$ of the muscle of freshwater eels starts to decrease gradually with the lapse of storage period regardless of the storage temperature but the rate of decrease in $\mathrm{pH}$ in samples stored at room temperature is much rapid than those stored in ice. The keeping quality of the freshwater $M$. armatus was found in acceptable condition up to 24 days and of $M$. aculeatus and $M$. pancalus up to 28 days in ice storage in insulated box by organoleptic, biochemical and microbial evaluations. 


\section{Literature Cited}

Abe, H. and E. Okuma, 1991. Rigor mortis progress of carp acclimated to different water temperatures. Nipp. Suis. Gakk., 57: 2095-2100.

AOAC., 1990. "Official Method of Analysis". 15 $5^{\text {th }}$ ed. Association of Official Analytical Chemists. Washington DC.

AOAC., 2005. "Official Method of Analysis". 18 $8^{\text {th }}$ ed. Association of Official Analytical Chemists. Washington DC.

Bito, M., K. Yamada, Y. Mikumo and K. Amono, 1983. Studies on rigor-mortis of fish-1. Differences in the mode of rigor-mortis among some varieties of fish by modified cuttings method. Bull. Tokai Reg. Fish. Res. Lab., 109: 89-96.

Chakraborty, S.C., M.B. Uddin and M.N. Islam, 2003. A study on proximate composition of common fresh water fishes of Bangladesh. Bangladesh J. Fish., 26(1-2): 23-36.

Connell, J.J., 1975. Quality deterioration and extrinsic quality defects in raw materials. In: control of fish quality. 2nd. ed. Fishing New Books Ltd. Surrey, England. 31-35.

Egan, H., R.S. Kirk, and R. Sawyer, 1981. Person's Chemical Analysis of Food. 8th ed. London. Churchill living stone.

Faruk, M.A.R., 1995. Studies on the post-mortem changes in rohu fish (Labeo rohita). M.Sc. Thesis, Department of Fisheries Technology. Bangladesh Agricultural University, Mymensingh.

Frazier, W.C. and Westhoff. 1990. Contamination, preservation and spoilage of fish and other seafood. In: Food Microbiology 3rd Ed. Tata McGraw Will Publishing Company Limited. New Delhi. 243-255.

Howgate, P.A.J. and K.J. Whittle, 1992. Multilingual Guide to EC Freshness Grades for Fishery Products. Torry Research Station, Food safety Directorate, Ministry of Agriculture, Fisheries and Food, Aberdeen, Scotland.

Hye, M.A., H.S.G. Fernando, H.G. Rana and M. Maniju, 1990. Effects of the use of Insulation and Ice in fish preservation., Bangladesh J. Agril. Sci., 17: 39-44.

Iwamoto, M., H. Yamanaka, S. Watabe and K. Hashimoto, 1987. Effect of storage temperature on rigor mortis and ATP degradation in plaice muscle. J. Food Sci., 52: 1514-1517.

Kamal, M., 1977. A comparative nutritive qualities of some of the commercial marine fishes of Bangladesh. M.S. thesis, Bangladesh Agricultural University, Mymensingh, Bangladesh.

Kamal, M., S. Gheyasuddin, S.C. Chakraborty, M.A. Hossain, M.A.R. Faruk and M.I. Hossain, 1994. Development for handling, transportation and processing of high quality hilsa fish. I. Studies on organoleptic characteristics on the quality changes in hilsa during ice-storage. BAURES. Prog. No. 8.

Konusu, S., K. Watanabe and T. Shimizu, 1974. Distribution of nitrogenous constituents in the muscle extracts of eight species of fish. Bull. Jap. Soc. Fish., 40(9): 909-915.

Poulter, R.G., C.A. Curran, B. Rowlands and J.G. Disney, 1982. Comparison of the biochemistry and bacteriology of tropical and temperate water fish during preservation and processing. Paper presented at the Symposium on Harvest and Post- Harvest Technology of Fish, Cochin, India, Trop. Dev. and Res. Inst., London.

Rubbi, S.F., M. Musleuddin, M. Begum, M. Jahan, S. Shamim and A.T.A. Ahmed, 1985. Handling of six species of fresh fish of Bangladesh. FAO Fisheries Report No. 317 suppl: 108-122.

Seely, J.R.W.H. and P.J. Vandemark, 1972. Microbes in action. Second edition. W. H. Freeman and Co. San francico., 52-55.

Tarr, H.L.A., 1965. Chemical control of microbiological decomposition. In: Fish as Food, Vol. 1 (ed. G. Borgstrom). Academic Press, New York.

Watabe, S., M. Kamal and K. Hashimoto, 1991. Post mortem changes in ATP, creatine phosphate and lactate in sardine muscle. J. Food. Sci., 56: $151 \neg 154$.

(Manuscript received 23 May 2020) 